\title{
THE RELEVANCE AND EFFICACY OF MARKETING IN PUBLIC AND NON-PROFIT SERVICE MANAGEMENT
}

\section{G. H. Wright, C. Chew and A. Hines}

\author{
Professor Gillian H. Wright * (corresponding author) \\ Business School \\ Manchester Metropolitan University \\ Manchester \\ United Kingdom \\ g.wright@mmu.ac.uk
}

\section{Dr Celine Chew}

University of Cardiff

University of Cardiff

Cardiff

United Kingdom

chewc@,Cardiff.ac.uk

\author{
Professor Anthony Hines \\ Business School \\ Manchester Metropolitan University \\ Manchester \\ United Kingdom \\ a.hines@mmu.ac.uk
}

Key words: marketing user focus nature of PNSOs service

Gillian Wright is Professor of Strategic Marketing in the Business School at Manchester Metropolitan University Business School. Her research concerns service quality and user orientation in public service.

Celine Chew is Senior Lecturer in Marketing and Strategy at Cardiff Business School, University of Cardiff. Her research is focused on the interface of theory and practice in strategy, marketing and public policy and the strategic management of public and voluntary non-profit organizations and social enterprises.

Tony Hines is Professor of Marketing in the Business School at Manchester Metropolitan University Business School. His research examines organizational structures, strategies and relationships, supply chains and globalisation. 


\title{
THE RELEVANCE AND EFFICACY OF MARKETING IN PUBLIC AND NON-PROFIT SERVICE MANAGEMENT
}

\begin{abstract}
The central premise of this paper is that public and non-profit service organizations (PNSOs) seek to add value to their multiple stakeholders with their multiple objectives. With the nature and difference of PNSOs in mind, we consider the relevance and the potential impact that a market-led orientation and the various elements of a strategic marketing approach to PNSO management can have on service outcomes and value. We conclude that although PNSOs utilize some management theorems effectively, there is potential for marketing concepts to make a significant contribution to the effective management of public services in contemporary society.
\end{abstract}

\section{INTRODUCTION}

Although public and non- profit service organizations (PNSOs) have imported generic management theorems to good effect, it is acknowledged, that there is scope to develop much further (Desmarais and de-Chatillon 2010; Osborne 2010 ), a research-based management perspective in the public service arena, whilst being mindful of the need to temper private sector models with public service realities (Crilly et al. 2009). This paper considers how the adoption of a market-led approach is relevant to planning and service delivery in PNSOs. We consider the context of public and non-profit organisations to encompass those entities that have a social agenda, distinct from the commercial objectives of the private sector. This paper contributes to the debate on the need to influence managerial practice in PNSOs that are increasingly faced with the need to balance organisational efficiency inclusiveness and the reduction of social inequalities in contemporary society.

Previous research in the PNSO domain has focussed on operationalizing constructs such as strategising, leadership and access. This paper is based on the extant research in marketing and the 


\section{Public Management Review}

potential of its underlying philosophy - emphasising meeting diverse stakeholder needs - to contribute to the effectiveness of the PNSO sector.

We argue that if PNSO management is to be demonstrably effectual, it must contribute to the value experienced by its multiple stakeholder groups. Marketing is concerned with balancing internal and external perspectives and expectations, based on synthesis of market-focused and internal knowledge (Lings 2004). Marketing in professional services is challenging because these services are based on knowledge, skills and expertise and so trust forms an important part of the relationships with stakeholders (McLaughlin et al. 2009). Public and non-profit services are particularly complex, covering a wide range of service categories driven by multiple stakeholders and varying levels of need. At the heart of marketing strategy remains the notion of the co-creation and delivery of services to add stakeholder value (Grönroos 1997) and that through the idea of a value chain, all organizational activity should contribute to stakeholder value.

In the context of current thinking in organisational strategy and marketing, this paper first considers the contemporary issues in service including the nature of service, service dominant logic and absorptive capacity. As a precursor to addressing the usefulness of marketing in PNSOs, we pose the question 'are public and non-profit organisations different?' We review the debate on the theoretical/conceptual differences in the operating environment of PNSOs and commercial organizations in terms of : objectives and measures of success; the nature of PNSO offerings; indirect payment/receipt linkage and serving multiple constituencies. From here we consider how the challenges of delivering (professional) public and non-profit services could benefit from the application of marketing constructs to achieve the desired service outcomes. We conclude by reinforcing the various ways that marketing has and can contribute to the effective management of public and non-profit services in practice.

\section{THE NATURE OF SERVICE}

The current focus of the contemporary discourse on service management is the idea that service implies exchange and exchange implies value, and so this warrants special attention as the basis for 
the following discussion of the nature of PNSOs and subsequently of the fundamental thinking in marketing. We offer the distinction between service and services as an important difference that can form a useful consideration in the management and delivery of PNSO offerings.

The nature of service is such that each party engages in relationships through which each gives and receives value through a process of exchange. Historically exchange has been viewed as transactional, for example in the purchase of goods or the purchase of services. However, in many respects this differentiation between goods and services is a false dichotomy in modern economies where both goods (tangibles) and services (intangibles) are subordinate to a broader notion of service (Christopher et al. 1993; Achrol and Kotler 1999; Hult 1999; Bateson and Hoffmann 1999 [1989]; Brodie 2009). If we extend this argument and apply it to the constructs of public and private services then we propose a notion of service that transcends this divide (Vargo and Archpru 2009). All exchange becomes exchange of service. Service itself becomes the value creation process. Thus, constructs such as public v private; goods v services, simply become co-relates of service. In adopting this line of argument we align closely with the service dominant-logic argument developed in the marketing discipline which is explained further below.

\section{Service dominant-logic}

There is an argument articulated in the extant literature that public and private organizations differ in their intentions and activities, which leads to observed difference in the way in which organizations view customers or service users. The discourse adopted give rise to further difference in how customers or service users view the supplier or provider of service (Vargo and Lusch 2004b). Thus, the discourse constructs both meaning and identity. There has been an emerging trend in service literature since the 1980 s to move towards a position that is rendered as a notion of 'Service dominant-logic' (SD-L), (Vargo and Lusch 2004a). This removes the notion of difference between suppliers of goods and services with an 's' (retail, health, education) and argues that service transcends both, when considered as a value creation process (Vargo and Lusch 2008). It is 


\section{Public Management Review}

recognized and proposed in this notion of service that it informs the way that organizations interact with service users acknowledging co-creation as an important element of service. There is a move away from the notion of service interaction as pure transactions towards service as a relationship that adds value. It is a powerful argument that acts as a catalyst to think about organizational interactions and service organizations in a different way.

\section{Absorptive capacity}

A parallel relevant discussion developed in the innovation literature since the 1990s about how resources are not necessarily fixed as previously assumed in economic models of the 'theory of the firm'. Economists pursue a discourse of factors of production (land, labour and capital). Many of their assumptions about organizational behaviour rested on notions of finite quantities of resource reinforcing a discourse of products and services (Williamson 1964). More recently discourse in economic innovation has acknowledged that organizations have 'absorptive capacity'(Cohen and Levinthal 1990). This concept recognizes that people in organizations can absorb ideas that change the ways in which a firm is organized and operates to create service more effectively through a combination of learning and innovation, without necessarily needing access to further resource. Rather than organizations having static capabilities, path dependency and fixed resource endowments, it has been argued that organizations possess potential dynamic capabilities, that if realized lead to different outcomes (Zahra and George 2002). It is in the nugget of this notion that the seeds of change exist to think differently about public service and service delivery per se.

\section{Synthesizing the notions of service and absorptive capacity}

These two conceptual strands of discussion are particularly important when considering service, value, exchange and co-creation. These two particular concepts help people inside organizations and policy-makers think differently about organizations; both what they do and how they do it, and perhaps more importantly when we consider public service what could be done by focusing attention 
on the service concept developed in the marketing discipline. Therefore, it is argued that adopting service as a notion that transcends the goods $v$ services, and public $v$ private debates helps organizations and networks think about what they do differently, transcending the description of difference. Absorptive capacity is a means of transforming an organization's ability to create service. It is also a way of allowing policy makers to think differently about service systems design. This synthesis suggests a return to the underpinnings of the notion of public service and so, in this sense, it is argued that the dichotomy of public and private sectors does not hold, rather there is theoretical and practice convergence between them. The next section re-examines the question are PNSOs different and if so are these differences significant and do they present theoretical challenges?

\section{ARE PUBLIC AND NON-PROFIT SERVICE ORGANIZATIONS DIFFERENT?}

Debate about the transference of notions of marketing that were founded on commercial (for-profit) principles to non-profit organizations began with a call to broaden the concept of marketing (Kotler and Levy 1969). From the philosophical question of whether it is right for perceived commercial principles to be transplanted into PNSOs this debate has moved to the more managerial issues of what marketing approaches and tools are appropriate for PNSOs and how to adapt them (Chew 2009). Criticisms centre on the challenges in adapting the marketing concept to a non-market context due to claimed differences between the operating contexts of PNSOs and commercial organizations. It has been argued that external institutional and policy factors driving PNSOs to adopt marketing behaviour are highly individualistic and self seeking in nature (McLaughlin et al. 2009). Furthermore, it has been suggested that PNSOs have been drawn into market scenarios that prioritize competition and adversarial relationships over collaborative and cooperative ones both between PNSOs and within them (Palmer 2001). The distinctive nature of the PNSO and the nature of their

offerings need consideration if marketing is to be relevant for them (Lovelock and Weinberg. 1989). The nature of PNSOs has been considered in the management, marketing, social and public policy literature, and four key differences have been espoused over the 30 years of this debate (Octon 1983; 


\section{Public Management Review}

Walsh 1991; Burton 1999; Hudson 2002; Andreasen and Kotler 2009; Chew 2009; Sargeant 2009).

These differences are: the emphasis on non-economic objectives and social value; services not products; an indirect link between payment and receipt; multiple and complex stakeholders. Each of these is now discussed in tern to address the question posed about difference and its significance.

\section{The primacy of non-economic objectives and measures of success}

PNSOs do not seek to generate profit for distribution to owners per se and it is this lack of a profit imperative linked directly to the ownership/governance structure of PNSOs that is the foundation for this claim of difference. However, it is worthy of note that the lack of a profit motive does not negate the financial focus of PNSOs. They are required to manage very large funds to ensure best value to donors and service beneficiaries and thus there is an implicit obligation to bring generic management skills, embodied in financial management to the PNSO context.

Many PNSOs arguably neither seek a financial surplus nor expect operating revenues to cover full operating costs, and so their mission statements tend to give priority to non-financial objectives, with the focus on social value as their bottom-line (Lovelock and Weinberg. 1989; Chew 2009). It is suggested that the lack of profit or financially driven motive in PNSOs deprives them of a clear basis for performance indicators compared to commercial organizations (Drucker 1990; Bryson 1995). Thus PNSOs tend to orientate towards non-financially focused performance measures such as service usage, level of service quality, client or user satisfaction, rather than the financially driven outcomes commonly used by for-profit entities that focus on market share, profitability or return on investment (Leat 1995; Courtney 2002). Hence, from a marketing perspective, it is relatively difficult to use traditional business measures to evaluate the success of a PNSO's strategy or marketing efforts (Lovelock and Weinberg. 1989). Therefore, other indicators of success evaluating the impact PNSO's activities are needed to compensate for the lack of PNSO financial bottom-line (Sawhill and Williamson 2001). Conversely, robust financial management is needed for the most effective use of financial resource to facilitate non-profit outcomes and to respond to public and institutional scrutiny. 


\section{The nature of public and non-profit service offerings}

The literature on non-profit marketing suggests that most PNSOs deal primarily with offerings that involve services, ideas and social behaviour instead of physical products (Lovelock and Weinberg. 1989; Bruce 1998 ; Burton 1999; Sargeant 2009). However, the range of public service offerings is not a homogeneous grouping but lie along a diverse spectrum of services that involve private and public/social benefits provided by a diverse number of PNSOs (Laing 2003). Those offerings that provide predominantly private benefits (e.g. housing, public transport, leisure and adult education) allow individual consumer judgement and demand in shaping decisions regarding usage, which in turn influences the supply of such services. Offerings that provide essentially social/public benefits (e.g. public health, defence and criminal justice) require professional judgement by PNSOs' managers in deciding the production and distribution of these services (Walsh 1991). The complex nature of public service offerings therefore affects the relationship between PNSOs and the consumers/citizens in different ways that extends beyond a purely economic-transactional perspective (Howard and Sheth 1969; Laing 2003). Policy and social considerations predominate and PNSOs are subjected to greater public visibility and thus scrutiny reflecting either the political process or media interest, or both (Lovelock and Weinberg. 1989), whilst economic rationality is secondary (Graham 1994).

\section{An indirect payment-receipt linkage}

The challenge of measuring success using economic indicators in PNSOs is complicated by a weak link between the users/beneficiaries (the party who consumes the services of the PNSO) and the funder/donor (the party who pays for these services) compared to commercial (for-profit) organizations. This requires two separate but interrelated systems in a PNSO to manage its relationship between the two parties effectively - one involving functions/activities to attract 


\section{Public Management Review}

resources, and another concerned with functions/activities to allocate these resources in pursuit of social missions and organizational goals (Mason 1984; Andreasen and Kotler 2003).

The ways in which public and non-profit organizations acquire their income are significantly different in terms of the nature of exchange/transaction compared to those of commercial organizations (Hudson 2002). In commercial transactions the customer purchases a product or service from the organization and pays the agreed price. The inherent funding dependency of PNSOs on external parties for financial resources means that they are dependent on funders/donors including central and local government, grants and voluntary donations to pay for services provided to users/beneficiaries (Chew 2009).

There is thus an indirect flow of resources from funder to user/beneficiary through the non-profit organization. Moreover, the variety of revenue sources of PNSOs signals the willingness of different parties: donors, citizens, taxpayers, government, other voluntary and non-profit organizations to support their activities, thereby providing social legitimacy for their cause/mission (Moore 2000).

\section{Serving multiple constituencies}

Undertaking both resource attraction and allocation activities means that they must deal with and balance the expectations of (at least) two sets of constituencies - the users/beneficiaries of their offerings, and those supplying resources to fulfil their organizational missions (Andreasen and Kotler 2009). Concurrently, there are other stakeholders including volunteers, central/local government agencies, contracting partners and the wider community indirectly affected by the strategies and performance of the PNSOs (Chew 2009).

Accountability is 'the means by which individuals and organizations report to a recognized authority(ies) and are held responsible for their actions' (Edwards and Hulme 1996) and serving multiple constituencies complicates PNSO accountability to their multiple stakeholders (Hudson 2002). For instance, the boards of directors and trustees of PNSOs in the UK are legally accountable to fulfil their organization's mission and to serve their primary stakeholders - citizens, users and 
beneficiaries. They are also financially accountable to their respective benefactors - central or local government departments, agencies or reporting commissioners. Moreover, they are expected to demonstrate social accountability by virtue of their social/public service purpose and the need to demonstrate public benefit to a wider array of stakeholders that could be affected by their activities (Ebrahim 2003).

Conceptualizations of marketing as network-based and relationship frameworks are thus advocated for PNSOs that are highly dependent on external parties for information, resources and capabilities, and demonstrate the characteristics that distinguish them from commercial entities. These models accommodate new levels of complexity to exchange relationships, which are arguably appropriate to the practice of marketing in contemporary PNSO contexts, going beyond the scope and utility of traditional transactional models of marketing (Laing 2003; Rees and Gardner 2003; McLaughlin et al. 2009). Even though there may be some elements of the nature of PNSOs that lead to the impression of a wide commonality, not all dissimilarities can be construed as an overall difference, necessitating a separate generic organisational classification. Theoretical (definitive analytical statements), empirical (what managers are actually doing in practice) and normative (what practices are prescribed) differences do not in themselves establish the need for different management approaches in PNSOs compared to commercial organisations (Leat 1995). This conclusion suggests that marketing as a discipline may offer useful insights into PNSOs and it is to this that we now turn our attention.

\section{PUBLIC/NON-PROFIT SERVICES AND MARKETING}

The following sections review the concepts of marketing and market orientation, and the notions of the customer and customer behaviour, services marketing, service-quality and professional services, strategic marketing and relationship marketing. For each of these central tenets, we explore its implications and usefulness for the effective and efficient delivery of public and not for profit services. In order to achieve this, we draw on some of the seminal works by scholars that have driven 


\section{Public Management Review}

the development of marketing thought. We consider how marketing and its constituent elements can be constructed to encompass the needs of PNSOs in the context of our discussion of their nature and previously proposed difference.

\section{The marketing concept}

Marketing has developed as a function and an organizational orientation (Borden 1964; Bagozzi 1975; Kotler 1986; Judd 1987; Kotler 1992), emphasizing the needs of the customer rather than those of the producer and the importance of relationship management (Dixon and Blois 1983; Hamel and Prahalad 1994; Gronroos 1996) and service as a means of creating value (Lusch et al. 2010).

Market orientation prioritizes customer needs and aligns organizational competencies to satisfy these, it is concerned with being market-led and delivering appropriate offerings in ways accessible and acceptable to users. A market orientation is long-established as an effective approach to organizational success (Fritz 1966; Cooper 1994; Avlonitis and Gounaris 1997; Kumar et al. 1997; Pelham 1997). Furthermore it emphasises information-based foci on customers and competitors (Narver and Slater 1990; Van-Egeren and O'Connor 1998; Heiens 2000 ). In strategic terminology market orientation is based on an external (service users, donors, competition) view rather than an inside view of the world (DeWit and Meyer 1999). There are a number of justifications for the market orientation of PNSOs: they are expensive to provide; important to the health and wellbeing of a community; necessary rather than optional; accountable and have quantified strategic objectives. To achieve their objectives, they need the effective interaction with, and the cooperation of those to or for whom their services are provided.

Early definitions of marketing assumed a profit maximisation imperative taking their lead from an economist world view. This simplistic approach to the presumed goals of commercial organizations led commentators to initially reject the concept of marketing as fundamentally inappropriate for PNSOs. However, in the commercial sector, marketing has become an approach to operations that delivers value and hence long-term sustainability of an organisation and this is the presumption of 
current thinking about relationship marketing. Thus, in increasingly competitive markets, profit as the key imperative, is often sacrificed to maximize market share and thus volume of activity rather than margin becomes the strategic goal. In the PNSO sector, the need for financial transparency and accountability is now well-established and these organizations employ strategic approaches that demonstrate value to their stakeholders. Thus, the private and PNSO sectors have converged in their organisational aims of value and effectiveness, to a position where marketing has become an approach useful to both.

It is a well-rehearsed argument that the public sector has social aims that are not present in the private sector. This is becoming less of a distinction. In the non-profit sector, organizations must show that public benefit is achieved not just effectively, but also efficiently and with stakeholders in mind. For instance, UK health and social care policy has been quite explicit in the language it uses to address the delivery of services in a customer focused way (DoH 2007; DoH 2009). Likewise, in the commercial sector, government policies on product licensing; safety and public health; environmental impact and wider corporate social responsibility have led to more complex structures of stakeholders and reducing the level of autonomy of private organisations which can no longer operate without considering the social implications of their activity.

\section{The notion of the customer in a public service context}

The notion of the customer is perhaps one of the most contentious issues in the application of marketing ideas in PNSOs. Debate remains about the nature of the PNSO customer, and whether the user is, in fact, a customer in the private sector sense (Chew and Osborne 2009b). We argue that if public management is to be demonstrably effectual, it must contribute to the value experienced by its multiple stakeholder groups (Wright and Hogarth-Scott 1996). Furthermore, stakeholder groups equate to the notion of the customer roles of initiator, information seeker, decision-maker, purchaser, consumer or evaluator roles. Services often have specific labels to describe their customers such as 'passengers', 'clients' and 'users'. In PNSOs equivalent labels include 'patients', beneficiaries', 


\section{Public Management Review}

'constituents', 'victims', 'students' and 'donors'. This does not make PNSOs different, rather it makes them quite typical of service offerers.

Our discussion of sectoral differences highlights that the nature of non-profit services as being free or subsidised at the point of consumption has, and continues to be, put forward forcefully as a reason that the user of public/non-profit services is not a customer in the conventional sense of someone who pays directly for a service. However, increasingly, the users of such services are more aware of what is available, what they can expect and what choices they are limited to. Spending and policies for non-profit organisations have become both newsworthy and often the platform for political campaigns. Thus, the user, as a customer, is targeted with messages that encourage them to behave as such in both their interactions with services, and more fundamentally in their voting behaviour. Taxation too, is a major political issue and the public are encouraged to vote for political candidates that will deliver the best in public service provision, this is especially pertinent as personal income tax generates far more government revenue than corporate taxation (Adams and Browne 2009). In the voluntary and charitable sector, there is increasing visibility of the ways in which donations are used, especially with respect to administration costs. Furthermore, there are a number of customer roles, of which the consumer is one. It is a wide-spread phenomenon of markets that relatively little purchasing is for personal consumption: shoppers are not necessarily consumers. In the private sector, supermarket shopping for a whole household may be undertaken by one person. The choice of products purchased may be influenced strongly by consumers, but they do not acquire and purchase goods. Major consumer items - holidays, white goods, cars and houses are all examples of where there are a number of customer roles. Understanding customer roles is important in non-profit services; not all customers are consumers, but certainly all consumers are customers.

A fundamental element of customer's behaviour is to understand the ways in which they are influenced, both as individuals and as members of groups. As individuals, people are influenced by their motivation, attitudes and personalities. They are also influenced by the multiple social groups they belong to such as family, work groups and social groups, as well as demographic trends. 
Understanding of customer behaviour is derived from a number of disciplines including sociology, psychology, economics, human geography and social history and there is no evidence that these influences are different between PNSO and commercial contexts.

\section{Services marketing}

The distinction between products and services began with an acknowledgement and description of their difference (Lovelock 1981; Lovelock and Gummesson 2004), specifically suggesting that services are intangible, variable, perishable and inseparable for those who deliver them. By recognising these differences and understanding the challenges they present, PNSO managers, can deliver services more effectively. From describing the nature of services, appreciation of the complexities of service-quality grew. Quality is focused on user experience of, and interaction with, services in terms of access, reliability, credibility, security, understanding, responsiveness, courtesy, competence, communication and tangibles (Parasuraman et al. 1985; Parasuraman et al. 1994). Despite debate about the operationalization of these factors, they continue to form the basis of measuring and managing the service quality. Satisfaction is also prominent in service marketing literature, and though clearly linked to quality, this relationship continues to be a fascinating area of research. Satisfaction, and the resultant perceptions and memories of an experience inevitably impacts on how users interact with and are compliant with service, including PNSO offerings (Proctor and Wright 1997; Martin-Hirsch and Wright 1998; Proctor and Wright 1998; Quader 2009). As services are co-produced and consumed, delivering effective service to a satisfied user will be easier than to a dissatisfied one. History shows apparent dissatisfaction with PNSOs leads to policy intended to police quality and satisfaction, and hence to outcome targets aimed at improving experience and thus satisfaction (Newsome and Wright 1999). PNSO providers might have more leeway in their service design if they took on board the principles of quality and satisfaction before they are forced into this by inflexible metrics embedded in policy. 


\section{Public Management Review}

\section{Professional services}

Marketing in professional services is challenging because these services are based on knowledge, skills and expertise and so trust forms an important part of the relationships with stakeholders.

PNSOs have complex offerings, covering a wide range of service categories driven by varying levels of need and thus differing levels of embedded trust.

The lack of customer orientation in public services is at least exacerbated by, and could well be largely explained by, the dominance of professional groups in PNSOs, who are responsible for their own skills and service which was individual rather than team and stakeholder focussed (Kennedy 2001) and who are relatively indifferent to the importance of the intangible dimensions of service delivery (Gronroos 2004). These attitudes inevitably lead to an internal service focus rather than the more desirable stakeholder need around which service expertise should be recruited.

\section{Strategic approaches to marketing}

Strategic marketing is concerned with understanding the way organizations understand how different groups of people think and behave, developing appropriate offerings to particular target groups. Strategic marketing is a valuable approach to aid such planning in public and non-profit organizations and it is argued that strategic positioning plays a key role in the process of strategy development in non-profit organizations (Lauffer 1984; Lovelock and Weinberg. 1989; Wright and Hogarth-Scott 1996; Hudson 2002; Andreasen and Kotler 2003; Wright 2005; Chew 2009).

Strategic positioning is a management process within the organization to create a position of the organization and its offerings in the marketplace from its perspective (Chew 2003; Chew 2009). It is a deliberate, proactive and iterative process and involves key decisions at the corporate management level that are too important to be determined at the tactical levels (Zineldin \& Bredenlow 2001). Nonprofit organizations such as charities that deliver public services are adopting differentiation and focus (niche) positioning strategies to preserve their distinctiveness in an increasingly competitive fundraising environment (Chew 2006; Chew 2009; Chew and Osborne 2009a; Chew and Osborne 
2009b). The social mission provides a strong anchor for positioning by non-profit organizations, and has helped them to avoid mission drift. Moreover, strategic positioning at the organizational level is distinct from but provides direction for positioning at other (lower) operational levels (Webster 1994; Hooley et al. 1998) Hooley et al.1998).

Positioning at the operational/product level requires organizations to look for similarities in groups of users that go beyond the fact that they use their offerings. Segmentation requires looking for ways in which people are similar, rather than different. Targeting is the process of deciding which groups a service particularly wants to address and entails making a service offering appropriate to the groups an organisation wants to use the service. One of the fundamental objections to marketing in nonprofit services is that it is not needed as a selling function - there is no need to persuade people that they want the product - they need it and public services operate in an environment of over-demand. An ongoing challenge to public sector managers is thus how to encourage users to engage with services appropriately.

\section{Relationship Marketing}

Relationship marketing is the current thinking behind effective long-term marketing strategies and forms an approach that underpins marketing management with a philosophy that guides an organisation towards adding value to its users. Relationship marketing emphasizes the distinction between two drivers for an organization: (i) the functional aspect of marketing activity, the marketing mix, and (ii) the strategic philosophy of market orientation (Wright 2007). Managing the traditional marketing mix in the context of buyer behaviour became the foundation of marketing for two decades (Borden 1964; Bagozzi 1975; Kotler 1986; Judd 1987; Kotler 1992). Strategic marketing, advocating segmentation, targeting and positioning, concentrates on finding ways of grouping customers based on homogeneous aspects of behaviour or motivation. The mix has been enhanced with physical evidence people and processes (service blueprinting) as service-specific items (Lambert and Harrington 1989; Collier 1991). 


\section{Public Management Review}

With the developing emphasis on strategic relationships, the focus in relationship management is on what an organization can do for a customer rather than how transactions can be sought and completed (Dixon and Blois 1983; Hamel and Prahalad 1994; Gronroos 1996). This suggests the need to go beyond multiple transactions, in effect shifting the emphasis from volume to value. Relationship marketing can be seen in a comprehensive management and social context (Gummesson 2002) in which value is jointly created. Relationship quality (Gummesson 1998), acknowledges the nature of relationships as a component of customer perceived quality (Storbacka et al. 1994; Holmlund 1997) and thus is a central issue in relationship marketing.

Relationship marketing is also an interesting lens through which to reflect on notions of internal markets and internal marketing (Wright and Taylor 2003; Wright and Taylor 2004). Relationship marketing emphasises the need for service supply chains to work co-operatively and seamlessly to deliver a service that is focused on user experience, not on their own silos of production and internal performance indicators. By doing so value is created with, and assessed by, the customer. Related to this, internal marketing is about service deliverers as stakeholders who add value to the wider range of stakeholders. Those inside an organisation are important because their knowledge, skills and commitment impacts on service quality. In this sense staff are an important group for managers to address, ensuring that they are committed to delivering an appropriate quality of service, making internal communication and commitment a key issue for PNSOs..

\section{CONCLUSIONS}

It is accepted that management is a legitimate activity for PNSOs as they grapple with the many challenges of managing their organizations in an increasingly complex, user-led and competitive operating environment. We suggest that marketing is demonstrably a key element of the management approach to PNSOs. The current focus of marketing thought located in service dominant logic is the central tenet that synergises the established marketing construct that we have considered in this paper. That service dominant logic espouses the centrality of stakeholder value 
emphasises the relevance of marketing in the PNSO sector. This contribution addresses key marketing and service constructs in the context of PNSOs suggesting how the principles and constructs of marketing apply to the PNSO service sector. This differentiates ours from other contributions which address how policy and public service philosophy can accommodate marketing. Marketing provides a lens through which to respond to needs and provide benefits and the debate should now focus not on if marketing is appropriate, but how it can be best used in PNSOs. Furthermore, the political context of marketing decisions and actions mean that marketing in these sectors needs to be developed towards sophisticated models of marketing management (Burton 1999; McLaughlin, Osborne \& Chew 2009) and in achieving this, legitimacy will be fundamental (Dart 2004).

The literature that suggests difference in PNSOs dates back to the idea that marketing is focused on products rather than service and transactions rather than co-creation and relationships. It assumes that PNSOs have more complex stakeholder networks, governance and missions that for-profit organisations, though we argue that these differences are diminished in the contemporary organisational environment. PNSOs have missions to deliver benefits to users and value to multiple stakeholders. We suggest that current understanding of service and the constructs of marketing empowers the delivery of PNSO services without the need for adaptation beyond that which any organisation needs to undertake in the delivery of value. So though there are some unique features of PNSOs, we propose that there are sufficient generic service elements to make the marketing paradigm a useful lens through which to view these sectors. We argue that PNSOs are subject to accountability, quality imperatives and policies that encourage user focus, in the same way as services provided by commercial businesses.

Previously, though the idea of marketing has been refuted on principle, there is no evidence of a systematic approach to the evaluation of the usefulness of marketing constructs. Instead, the debate seems to have been one of principle rather than located in the practice of marketing. This contribution 


\section{Public Management Review}

sets the stage to refute the principle of the rejection of marketing in favour of the principle of the application of marketing in the contemporary environment of PNSOs.

We have highlighted that marketing concepts and approaches are relevant and useful for PNSO management, however as with all applications to the practice of management, considerations needs to be given to the specific nature of each PNSO context. The environment of these organisations is such that users and stakeholders have choices and expectations. Stakeholders, and in particular service users, taxpayers and the general community, now hold public service organizations more accountable for their decisions and actions that affect quality of life. Many of the traditional arguments against the application of marketing in PNSOs have rested on the assumption that their relationships with citizens/service recipients are quite distinct from private sector relationships between organization and 'sovereign customers' (Butler and Collins 1995). Our conceptualisation shows that marketing offers a more real opportunity to respond to the policy forces that shape and constrain their overall strategy in an environment in which trust, collaboration and cooperation dominate intra- and inter-organizational management and governance (McLaughlin et al. 2009). Despite this, the notion of marketing is still contentious in a service environment that views managerialism with scepticism. This paper revisits the underlying themes of marketing and suggests that marketing has a legitimate place in the delivery of effective service and achievement of servicequality objectives explicit in public policy.

This conceptual justification sets a future research agenda to contribute to the call for a new theory in delivering public services (Osborne 2010 ). Knowledge can be enhanced further through case studies of marketing practice, and research that establishes the underlying approaches to stakeholder responsiveness using the language of service and services marketing in response to understanding the issues of equity and excellence in PNSOs. Furthermore, the agenda of difference remains and this needs to be the focus of further discourse to underpin the application of marketing theory and techniques in public and non-profit organizations.

\section{REFERENCES}


Achrol, R. S. \& Kotler, P. (1999) Marketing in the network economy. Journal of Marketing, 63, 146.

Adams, S. \& Browne, J. (2009) A survey of the UK tax system. London, institute for Fiscal Studies.

Andreasen, A. \& Kotler, P. (2003) Strategic Marketing for Non-Profit Organizations, Upper Saddle River, Pearson Prentice-Hall.

Andreasen, A. \& Kotler, P. (2009) Strategic Marketing for Non-Profit Organizations, Upper Saddle River, Pearson Prentice-Hall.

Avlonitis, G. J. \& Gounaris, S. P. (1997) Marketing orientation and company performance: industrial vs. consumer goods companies. Industrial Marketing Management, 26, 385-402.

Bagozzi, R. P. (1975) Marketing as Exchange. Journal of Marketing, 39, 32-39.

Bateson, J. E. G. \& Hoffmann, K. D. (1999 [1989]) Managing services marketing - text and readings, Orlando, Dryden Press.

Borden, N. H. (1964) The Concept of the Marketing Mix. Journal of Advertising Research, 4, 2-7.

Brodie, R. J. (2009) From goods to service branding:An integrative perspective. Marketing Theory, 9, 107-111.

Bruce, I. (1998 ) Successful Charity Marketing: Meeting Need, London, ICSA Prentice Hall.

Bryson, J. M. (1995) Strategic Planning for Public and Non-Profit Organizations: A Guide to Strengthening and Sustaining Organizational Achievement, California, Jossey-Bass.

Burton, S. (1999) Marketing for public organizations. Public Management, , 1, 373-385.

Butler, P. \& Collins, N. (1995) Marketing public sector services: concepts and characteristics. Journal of Marketing Management, 11, 83-96.

Chew, C. (2003) What factors influence the positioning strategies in Voluntary Non-Profit Organizations? Towards a Conceptual Framework. Local Governance, 29, 288-323.

Chew, C. (2006) Positioning and its strategic relevance: emerging themes from the experiences of British charitable organizations. Public Management Review, 8, 333--50.

Chew, C. (2009) Strategic Positioning in Voluntary and Charitable Organizations, London, Routledge.

Chew, C. \& Osborne, S. (2009a) Exploring strategic positioning in the UK charitable sector: emerging evidence from charitable organizations that provide public services. British Journal of Management, 20, 90-105

Chew, C. \& Osborne, S. (2009b) Towards an integrating model of factors influencing positioning strategies in the UK charitable organizations. NonProfit and Voluntary Sector Quarterly, 38, 29-50.

Christopher, M., Payne, A. \& Ballantyne, D. (1993) Relationship marketing : bringing quality, customer service and marketing together, Oxford, Butterworth-Heinemann.

Cohen, W. M. \& Levinthal, D. A. (1990) Absorptive capacity: A new perspective on learning and innovation. Administrative Science Quarterly, 35, 128-152.

Collier, D. A. (1991) New Marketing Mix Stresses Service. Journal of Business Strategy, 12, 42-45.

Cooper, R. G. (1994) New products: the factors that drive success. International Marketing Review, $11,60-76$.

Courtney, R. (2002) Strategic Management for Voluntary NonProfit Organizations, London, Routledge

Crilly, T., Jashapara, A. \& Ferlie, E. (2009) Research Utilisation \&Knowledge Mobilisation A Scoping Review of the Literature. SDO Project Ref: 08/1801/220.

Dart, R. (2004) Being business-like in a nonprofit organization: A grounded and inductive typology. Nonprofit and Voluntary Sector Quarterly, 32, 290-310.

Desmarais, C. \& de-Chatillon, E. A. (2010) Are there still differences between the roles of private and public sector managers? Public Management Review, 12, 127-149.

DeWit, B. \& Meyer, O. (1999) Strategy synthesis, International Thomson Business Press.

Dixon, D. F. \& Blois, K. J. (1983) Some Limitations of the 4Ps as a paradigm for Marketing. Marketing Education Group.

DoH (2007) Our health, our care, Our say Department of Health. London. 
DoH (2009) The NHS Constitution - the NHS belongs to us all, Department of Health. London The Stationery Office.

Drucker, P. (1990) Managing the Non-Profit Organization: Practices and Principles, Oxford, Butterworth-Heinemann.

Ebrahim, A. (2003) Making sense of accountability: conceptual perspectives for northern and southern nonprofits. Nonprofit Management and Leadership, 14, 191-212.

Edwards, M. \& Hulme, D. (1996) Too close for comfort? the impact of official aid on nongovernmental organizations. 24, 6, 961-73.

Fritz, W. (1966) Market orientation and corporate success: findings from Germany. European Journal of Marketing, 30, 59-74.

Graham, P. (1994) Marketing in the public sector: Inappropriate or merely difficult? Journal of Marketing Management, , 10, 361-375.

Gronroos, C. (1996) Relationship Marketing: Strategic and Tactical Implications. Management Decision, 34, 5-14.

Gronroos, C. (2004) The relationship marketing process: communication, interaction, dialogue, value. Journal of Business and Industrial Marketing, 19, 99-113.

Grönroos, C. (1997) Value-driven Relationship Marketing: from Products to Resources to Values. Journal of Marketing Management, 13, 407-420.

Gummesson, E. (1998) Implementation Requires a Relationship Marketing Paradigm. Journal of the Academy of Marketing Science, 26, 242-249.

Gummesson, E. (2002) Relationship Marketing in the New Economy. Journal of Relationship Marketing, 1, 37-58.

Hamel, G. \& Prahalad, C. K. (1994) Competing for the Future. Breakthrough strategies for Seizing Control of your Industry and Creating the Markets for Tomorrow, Boston MA, Harvard Business School Press.

Heiens, R. A. (2000 ) Market Orientation: Toward an Integrated Framework. Academy of Marketing Science Review, 1.

Holmlund, M. (1997) Perceived Quality in Business Relationships, Helsinki, The Swedish School of Economics and Business Administration.

Hooley, G., Broderick, A. \& Moller, K. (1998) Competitive Positioning and the Resource Based View of the Firm. Journal of Strategic Marketing, 6, 97-115.

Howard, J. A. \& Sheth, J. N. (1969) The Theory of Buyer Behavior, New York, John Wiley \& Sons.

Hudson, M. (2002) Managing Without Profit: The Art of Managing Third-Sector Organizations, London, Directory of Social Change.

Hult, G. T. M. (1999) Discovering the Soul of Service: The Nine Drivers of Sustainable Success. Journal of Marketing, 63, 157.

Judd, V. C. (1987) Differentiate with the 5th P: People. Industrial Marketing Management, 16, 241 247.

Kennedy, I. (2001) Learning from Bristol: the report of the public inquiry into children's heart surgery at the Bristol Royal Infirmary, Chapter 22: The culture of the NHS, London, The Stationery Office, CM 5207; July.

Kotler, P. (1986) Megamarketing. Harvard Business Review, 64, 117-124.

Kotler, P. (1992) Total Marketing. Business Week Advance, 2.

Kotler, P. \& Levy, S. J. (1969) Broadening the concept of marketing. Journal of Marketing, 33, 1015.

Kumar, K., Subramanian, R. \& Yauger, C. (1997) Performance-oriented: toward a successful strategy. Marketing Health Services, 17, 10-20.

Laing, A. (2003) Marketing in the Public Sector: Towards a Typology of Public Services. Marketing Theory, 3, 427-445.

Lambert, D. D. \& Harrington, T. C. (1989) Establishing Customer Service Strategies within the Marketing Mix: more Empirical Evidence. Journal of Business Logistics, 10, 44-60.

Lauffer, A. (1984) Strategic Marketing for Not-for-Profit Organizations Free Press. 
Leat, D. (1995) Challenging Management, VOLPROF, London, City University Business School.

Lings, I. N. (2004) Internal market orientation: Constructs and consequences. Journal of Business Research, 57, 405-413.

Lovelock, C. (1981) Why Marketing Management Needs to Be Different for Services. IN Donnelly, J. \& George, W. (Eds.) Marketing of Services. Chicago, American Marketing Association.

Lovelock, C. \& Gummesson, E. (2004) Whither Services Marketing? In Search of a New Paradigm and Fresh Perspectives. Journal of Service Research, 7, 20-41.

Lovelock, C. \& Weinberg., C. (1989) Public and Nonprofit Marketing, Redwood City CA, The Scientific Press.

Lusch, R. F., Vargo, S. L. \& Tanniru, M. (2010) Service value networks and learning. Journal of the Academy of Marketing Science, 38, 19-31.

Martin-Hirsch, J. \& Wright, G. (1998) The development of a quality model: measuring effective midwifery services (MEMS). International Journal of Health Care Quality Assurance, 11, 50-57.

Mason, D. (1984) Voluntary Non-profit Enterprise Management, New York, Plenum Press., Dryden.

McLaughlin, K., Osborne, S. P. \& Chew, C. (2009) Relationship marketing, relational capital and the future of marketing in public service organizations. Public Money and Management Decision, $29,35-42$.

Moore, M. (2000) Managing for value: organizational strategy in for-profit, nonprofit, and governmental organizations. Nonprofit and Voluntary Sector Quarterly, 29, 183-204.

Narver, J. C. \& Slater, S. F. (1990) The effect of a market orientation on business profitability. Journal of Marketing, 54, 20-35.

Newsome, P. \& Wright, G. (1999) A review of patient satisfaction: 2. Dental patient satisfaction: an appraisal of recent literature. British Dental Journal, 186, 166-170.

Octon, C. M. (1983) A re-examination of marketing for British non-profit organizations. European Journal of Marketing, 17, 33-43.

Osborne, S. (2010 ) Delivering Public Services: Time for a new theory? Public Management Review, $12,1-10$.

Palmer, A. (2001) Co-operation and Collusion: Making the Distinction in Marketing Relationships. Journal of Marketing Management, 17, 761- 784.

Parasuraman, A., Zeithaml, V. \& Berry, L. (1985) A Conceptual Model of Service Quality and its Implications for Future Research. Journal of Marketing, 49, 41-50.

Parasuraman, A., Zeithaml, V. \& Berry, L. (1994) Reassessment of Expectations as a Comparison Standard in Measuring Service Quality: implications for Future Research. Journal of Marketing, 58, 111-124.

Pelham, A. M. (1997) Mediating Influences on the Relationship between market orientation and profitablility in small industrial firms. Journal of Marketing Theory and Practice, 5, 55-76.

Proctor, S. \& Wright, G. (1997) Can services marketing concepts be applied to Healthcare? Journal of Nurse Management 6, 147-153.

Proctor, S. \& Wright, G. (1998) Mission impossible? making sense of the key debates in the services marketing literature. Journal of Non-profit and Public Sector Marketing, 1.

Quader, M. S. (2009) Managers and patient perceptions of a quality outpatient service: measuring the gap. Journal of Services Research, 9, 109-138.

Rees, P. \& Gardner, H. (2003) Best Value, Partnerships and Relationship Marketing in Local Government. International Journal of Nonprofit and Voluntary Sector Marketing, 8, 143-152.

Sargeant, A. (2009) Marketing Management for Non-Profit Organizations, Oxford, Oxford University Press.

Sawhill, J. \& Williamson, D. (2001) Mission impossible? measuring success in nonprofit organizations. Nonprofit Management and Leadership, 11, 371-386.

Storbacka, K., Strandvik, T. \& Grönroos, C. (1994) Managing Customer Relationships for Profit: the Dynamics of Relationship Quality. Service Industry Management, 5, 21-38. 
Van-Egeren, M. \& O'Connor, S. (1998) Drivers of marketing orientation and perfrmance in service firms. Journal of Services Marketing, 12, 39-58.

Vargo, S. L. \& Archpru, A. M. (2009) Service-dominant logic as a foundation for service science: Clarifications. Service Science, 1, 32-41.

Vargo, S. L. \& Lusch, R. F. (2004a) Evolving to a new dominant logic for marketing. Journal of Marketing, 68, 1-27.

Vargo, S. L. \& Lusch, R. F. (2004b) The four service marketing myths: Remnants of a goods-based, manufacturing model. Journal of Service Research, 6, 324-335.

Vargo, S. L. \& Lusch, R. L. (2008) Service-dominant logic: continuing the evolution. Journal of the Academy of Marketing Science, 36, 1-10.

Walsh, K. (1991) Citizens and consumers: Marketing and public sector management. Public Money \& Management, 11, 9-16.

Webster, F. E. (1994) Market-driven management. Using the new marketing concept to create a customer-oriented company, London, Macmillan.

Williamson, O. E. (1964) The economics of discretionary behavior: Managerial objectives in a theory of the firm, Englewood Cliffs, Prentice Hall.

Wright, G. (2007) Are UK Healthy? Monash Business Review, 3, 14-15.

Wright, G. \& Hogarth-Scott, S. (1996) The quality of healthcare, GPs views. Marketing Intelligence and Planning 14, 45-51

Wright, G. \& Taylor, W. (2003) Strategic knowledge sharing for improved service delivery: managing an innovative culture for effective partnerships. IN Coakes, E. (Ed.) Knowledge Management: Current Issues and Challenges. Hershey PA, IRM Press.

Wright, G. \& Taylor, W. (2004) Organizational Readiness for Successful Knowledge Sharing: challenges for public sector managers. Information Resources Management Journal, 17, 2237.

Wright, G. H. (2005) Partnerships and User Focus. Public Management Review, 7, 203-224.

Zahra, S. A. \& George, G. (2002) Absorptive Capacity: A Review, Reconceptualization, and Extention Academy of Management Review, 27, 185-203. 